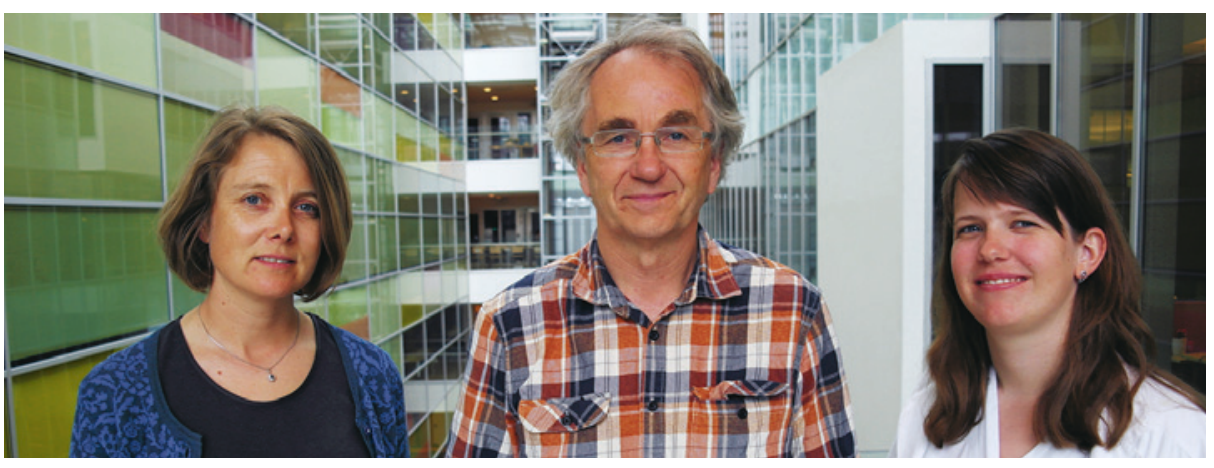

Fra venstre Kristin Moberg Aakre, Sverre Sandberg og Hilde Sellevoll. Foto: Ellen Gerd Valberg

\title{
Tolking av troponinresultater
}

Troponinverdiene varierer over tid, også hos dem som ikke har hjerteinfarkt. Troponin I-verdiene varierer mer enn troponin T-verdiene. Dette viser en ny norsk studie.

Akutt hjerteinfarkt diagnostiseres ut fra symptomer og kliniske funn. Samtidig skal pasienten i løpet av de første timene etter symptomdebut ha forhøyet konsentrasjon av troponiner, og konsentrasjonen av disse skal endres etter et spesifikt mønster. I enkelte pasientgrupper, f.eks. nyresyke, ses ofte kronisk forhøyet troponinkonsentrasjon. Hos disse kan man kun bruke endringer i konsentrasjon som biokjemisk kriterium for akutt infarkt. Hvor store disse endringene skal være før man sikkert kan stille en infarktdiagnose, har vært diskutert gjennom flere år.

Leger og forskere i Helse Vest har nylig undersøkt to høysensitive troponinmetoder, troponin $\mathrm{T}$ og troponin I (hs-Troponin T fra Roche Diagnostics og hs-Troponin I fra Abbot Diagnostics) med henblikk på hvilke konsentrasjonsendringer man ser i løpet av seks timer hos friske individer og hos pasienter i hemodialyse når disse er i stabil fase (behandlingsfri dag) (1).

Studien viste at den biologiske variasjonen hos det enkelte individ var relativt liten og lik i begge grupper. Hos friske individer er konsentrasjonen av troponiner svært lav. Da blir måleusikkerheten (analytisk variasjon) høyere. Totalt sett blir dermed de prosentvise naturlige svingningene størst hos friske individer. Både den analytiske og den biologiske variasjonen var større for troponin I-metoden enn for troponin T-metoden. For troponin I var den naturlige variasjonen i noen tilfeller tilsvarende det man har valgt å benytte som diagnostisk beslutningsgrense i definisjonen av akutt hjerteinfarkt. Blodprøvene ble samlet inn fra kl 0830 til kl 1430. I løpet av dette tidsrommet falt den gjennomsnittlige troponinkonsentrasjonen i begge gruppene.

- Dersom forskjellen mellom tropinin T og troponin I kan bekreftes i andre studier, bør man vurdere å innføre metodespesifikke diagnostiske kriterier også for endringer i troponinverdier, sier Kristin Moberg Aakre, avdelingsoverlege ved Laboratorium for klinisk biokjemi, Haukeland universitetssykehus, og førsteforfatter i studien. - Studien er viktig også fordi den kan bidra til bedre infarktdiagnostikk hos pasienter med alvorlig nyresykdom. Disse har høy risiko for iskemisk hjertesykdom, og relativt lite er kjent rundt tolking av troponinresultater hos denne gruppen, sier hun.

- Fallet i gjennomsnittlig tropininkonsentrasjon i løpet av formiddagen var et interessant bifunn. Dette var tydeligst for troponin $\mathrm{T}$. Det kan tyde på at det er en døgnvariasjon i troponinverdi. Dette er ikke tidligere beskrevet og bør derfor undersøkes nærmere, sier Moberg Aakre.

\section{Samarbeid}

Laboratorium for klinisk biokjemi og nyreseksjonen ved medisinsk avdeling ved Haukeland universitetssykehus, Laboratorium for medisinsk biokjemi ved Stavanger universitetssjukehus og forskningsgruppen ved NOKLUS har i flere år arbeidet for riktig diagnostikk av nyresykdommer. Laboratorium for klinisk biokjemi ved Haukeland universitetssykehus har dessuten deltatt $i$ arbeidet for å innføre retningslinjer for enhetlig infarktdiagnostikk i Norge. Gjennom dette arbeidet så man et behov for å gjennomføre studien. Andre viktige bidragsytere i studien var dialyseavdelingen i Helse Bergen, inkludert enhetene på Straume og Voss, og laboratoriet ved Voss sjukehus.

\section{Kari Tveito}

Tidsskriftet

\section{Litteratur}

1. Aakre KM, Røraas T, Petersen PH et al. Weekly and 90 -minute biological variations in cardiac troponin T and cardiac troponin I in hemodialysis patients and healthy controls. Clin Chem 2014; 60: $838-47$
Ordforklaringer

Høysensitive troponinmetoder: Troponin Tog troponin I er hjertespesifikke biomarkører, dvs. at de kun frigjøres ved skade av hjertemuskelceller. Nyere analysemetoder betegnes som høysensitive dersom de med høy grad av presisjon kan påvise målbare mengder troponiner hos $75-80 \%$ av friske individer.

Biologisk variasjon: Fysiologiske konsentrasjonsendringer for en komponent rundt et homøostatisk settpunkt. Endringene i påfølgende konsentrasjoner skyldes ikke sykdom, men naturlige svingninger.

Analytisk variasjon: Måleusikkerhet. Den variasjon man finner dersom man måler konsentrasjonen av en komponent flere ganger i samme prøve.
Artikkelen ble publisert i Clinical Chemistry, som er det ledende internasjonale tidsskriftet innen medisinsk biokjemi, i juni 2014. Den ble også ledsaget av en leder i samme nummer. 